\title{
DAKWAH POLITIK NABI MUHAMMAD KEPADA RAJA HERAKLIUS, KISRA ABRAWAIZ, MUQAUQIS, DAN NAJASYI
}

\author{
Agusti Alfi Nurul Insani \\ Pondok Pesantren Dar Al-Qalam Monash Institute Semarang \\ Email: agustialfi2018@gmail.com
}

\begin{abstract}
$D$

a'wah must be carried out using the right approach. Among the da'wah approaches is a political approach, called political da'wah. The practice of political da'wah has been exemplified by the Prophet Muhammad in the form of sending da'wah to rulers outside of Islamic rule. In this article, the author discusses the political da'wah of the Prophet Muhammad through a letter to four rulers, namely Heraclius, Kisra Abrawaiz, Muqauqis, and Najasyi. This study concluded that the Prophet Muhammad's political da'wah was a form of the head of state's political da'wah to the head of state. The da'wah method used is writing da'wah (da'wah bi al-qalam) through diplomacy strategies using letter media. Systematic of letters include the beginning of letters, letterhead, topic switching, contents of letters, and letter stamps. The Prophet Muhammad's letter contained an invitation to convert to Islam, good news (tabsyir), warning (tandzir), and also the verses of the Qur'an.
\end{abstract}

Keywords: Political Da'wah, Prophet Muhammad, Letter.

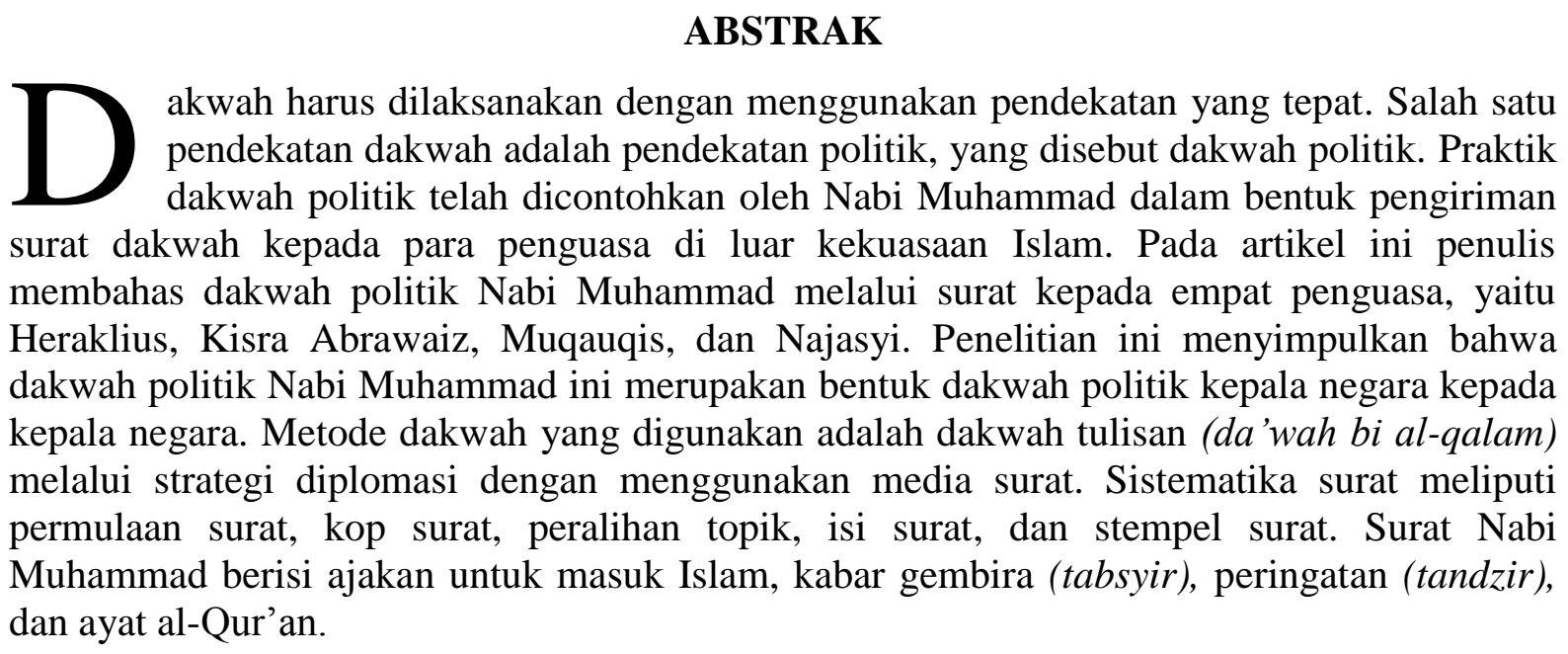

Kata-kata kunci: Dakwah Politik, Nabi Muhammad, Surat. 


\section{PENDAHULUAN}

Ajaran Islam diturunkan untuk umat seluruh alam yang memiliki beragam latar belakang ras, budaya, bahasa, dan kepercayaan. Keragaman latar belakang tersebut mengharuskan para $d a{ }^{\prime} i$ untuk memilih cara berdakwah yang tepat agar tujuan dakwah dapat tercapai. Sepanjang perjalanan dakwah Islam sejak Nabi Muhammad hingga sekarang, berbagai pendekatan, metode, dan strategi dakwah telah dijalankan oleh para $d a^{\prime} i$ mulai dari dakwah secara diam-diam kepada orangorang terdekat, hingga dakwah secara terbuka kepada masyarakat luas.

Pemilihan jenis pendekatan dakwah merupakan langkah awal yang harus ditentukan $d a{ }^{\prime} i$ sebelum menentukan strategi dan metode dakwah. Salah satu pendekatan dakwah menurut Mohamad Ali Aziz adalah dakwah politik, yaitu gerakan dakwah yang memanfaatkan struktur sosial dan politik untuk mencapai tujuan dakwah. Pendekatan politik berada pada lingkaran kekuasaan.

Politik sering dipandang kurang positif oleh masyarakat sehingga pendekatan dakwah politik menuai kontroversi. Pertama, pendekatan politik tidak seharusnya diterapkan dalam dakwah. Dakwah dan politik tidak dapat disatukan. Dakwah dipahami sebagai sesuatu yang sakral dan suci karena menyampaikan pesan-pesan Ilahiyah, sedangkan politik dipahami sebagai aktivitas keduniawian sebagai upaya merebut dan mempertahankan kekuasaan. Politik dianggap kerap melibatkan trik-trik yang tidak sesuai dengan norma-norma Ilahiyah. M. Amien Rais (1989: 23) dalam buku
"Cakrawala Islam, Antara Cita dan Fakta" menyebutkan:

"Hubungan fungsional antara
politik dan dakwah sering
tidak dimengerti dengan oleh
sementara kaum muslimin,
sehingga banyak yang
menganggap bahwa kegiatan
politik berdiri sendiri, terpisah
sama sekali dengan kegiatan
dakwah. Bahkan dalam
masyarakat kita. Ada kesan
kurang positif terhadap
kegiatan politik, seolah-olah
politik selalu mengandung
kelicikan, hipokrisi, ambisi
buta, pengkhianatan,
penipuan, dan pelbagai
konotasi buruk lainnya."

Kedua, pada dasarnya tidak ada pemisahan antara dakwah dan struktur atau politik. Politik adalah salah satu aspek kehidupan manusia, bagian integral dari agama yang tidak perlu dijauhi tetapi harus digauli (Sihombing, 2004: 2). Pendekatan politik tidak bertentangan dengan misi dakwah. Politik dapat dijadikan sebagai sarana yang efektif dalam dakwah. Politik atau siyasah adalah aktivitas atau sikap yang mengatur kehidupan manusia dalam masyarakat. Menurut Ibnu Khaldun (2000: 67-68), politik adalah sebuah mekanisme yang menjadikan manusia dalam masyarakat berjalan lancar menuju tujuan yang dicitakan bersama.

Politik sebenarnya sarat dengan nilainilai amr ma'ruf nahi munkar. Tujuan dan fungsi politik adalah untuk mencapai tatanan kehidupan masyarakat adil dan sempurna untuk mencapai tujuan bersama. Begitu juga dengan dakwah bertujuan untuk membentuk masyarakat yang penuh dengan ketenangan dan kedamaian serta

\section{Islamic Communication Journal Volume 4, Nomor 1, Januari-Juni 2019


Agusti Alfi Nurul Insani

tegaknya persamaan dan keadilan tanpa ada diskriminasi dan eksploitasi (Sihombing, 2015: 4).

Masyarakat Islam pada umumnya kurang melihat hubungan politik dengan agama dan berpadangan, bahwa keduanya harus dipisahkan. Islam dimaknai sebagai persoalan individu dan tidak dianggap sebagai persoalan sosial. Kuntowijoyo dalam Sukayat (2015: 127) menyatakan pentingnya kesadaran komunitas dan kerjasama untuk mewujudkan kemaslahatan, salah satunya adalah melalui aktivitas politik dalam wadah suatu negara. Al-Quran menyebutkan beberapa prinsip politik, yaitu keadilan, musyawarah, toleransi, hak dan kewajiban, kejujuran, amanah, amar ma'ruf nahi munkar, dan penegakan hukum. Contoh penerapan politik dalam dakwah Islam juga dicontohkan langsung oleh Nabi Muhammad.

Praktik dakwah politik telah dilakukan oleh Nabi Muhammad sejak awal dakwah Islam, terutama pada periode dakwah di Madinah. Kedatangan Muhammad ke Madinah bukan hanya membawa misi dakwah, tetapi juga menegakkan sebuah tata bangunan politik. Muhammad memerankan tugas ganda, yaitu sebagai pemimpin dakwah dan sebagai pemimpin politik negara Islam di Madinah. Semasa periode dakwah di Madinah Nabi Muhammad saw telah melancarkan berbagai kebijakan dakwah politik. Salah satu di antaranya adalah perluasan dakwah ke luar wilayah kekuasaan Islam. Pada akhir tahun $6 \mathrm{H}$ pasca Perjanjian Hudaibiyah Nabi Muhammad mengirimkan beberapa utusan untuk menyampaikan surat dakwah kepada para penguasa di luar
Jazirah Arab. Empat di antara para penguasa tersebut adalah Najasyi Penguasa Habasyah, Heraklius Kaisar Imperium Romawi, Kisra Kisra Abrawaiz Penguasa Persia, dan Muqauqis Penguasa Koptik Qibthi wilayah Mesir (Chalil, 2001: 392).

Romawi dan Persia pada saat itu merupakan dua imperium yang memiliki pengaruh besar dalam peradaban dunia. Dua imperium ini dikenal sebagai kubu yang saling berseteru. Pada tahun $6 \mathrm{H}$, Romawi berhasil mengalahkan Persia. Pasca perang inilah Nabi Muhammad mengirimkan surat dakwah kepada dua penguasa tersebut. Para pakar sejarah menyebutkan Dihyah menyampaikan surat kepada Heraklius ketika ia sedang menunaikan nadzar atas kemenangannya di Baitul Maqdis Ilya, Palestina. Selain itu Nabi Muhammad mengirim utusan kepada Kisra Penguasa Persia yang tengah dirundung kekalahan (Chalil, 2001: 394395).

Objek dakwah ketiga Nabi Muhammad yang penulis bahas pada artikel ini adalah Muqauqis Gubernur Mesir. Pada saat itu Mesir berada di bawah kekuasaan Romawi Timur. Mesir merupakan wilayah yang subur dan kaya, tetapi Mesir menjadi objek bagi penyiksaan berlatar belakang agama (karena pertentangan antara aliran agama dalam Kristen) dan kesewenangan politik yang mengerikan. Mesir dijadikan sebagai kambing perahan oleh Romawi. Mesir menjadi penyuplai kemewahan dan kekayaan bagi Romawi, tetapi masyarakatnya justru penuh penderitaan dan kesialan (An-Nadwi, 2005: 17).

Objek dakwah yang terakhir adalah Najasyi, Raja Habasyah. Habasyah merupakan wilayah yang penting bagi 
perkembangan agama Islam di tahap-tahap awal. Negeri ini memberikan suaka politik bagi para sahabat yang hijrah untuk menyelamatkan keimanan mereka dari desakan kaum kafir Quraisy. Nabi Muhammad bersabda, "Sesungguhnya di negeri Habasyah terdapat seorang raja yang tak seorang pun yang didzalimi di sisinya. Pergilah ke negerinya, hingga Allah membukakan jalan keluar bagi kalian dan penyelesaian atas peristiwa yang menimpa kalian". Sekarang pada saat Islam sudah kuat, Nabi Muhammad menyeru Najasy untuk memeluk Islam dan bersatu dalam kedamaian. Meskipun pada saat itu Najasy yang berkuasa sudah merupakan orang yang berbeda (An-Nadwi, 2005: 359).

Berdasarkan uraian di atas, artikel ini akan membahas tentang dakwah politik Nabi Muhammad melalui surat kepada empat penguasa, yaitu Heraklius, Kisra Abrawaiz, Muqauqis, dan Najasyi. Titik bahasan artikel ini meliputi analisis isi surat, bentuk, metode dan strategi dakwah politik Nabi Muhammad kepada para penguasa.

\section{METODE PENELITIAN}

Penelitian ini merupakan penelitian kualitatif, yaitu penelitian yang menghasilkan data deskriptif berupa ucapan, tulisan atau perilaku objek yang diamati. Pendekatan yang digunakan dalam penelitian ini adalah pendekatan historis. Pendekatan historis bertujuan untuk membuat deskripsi, gambaran atau lukisan yang sistematis, faktual, dan akurat mengenai fakta-fakta, sifat-sifat serta hubungan antarfenomena yang terjadi di masa silam. Fenomena yang dideskripsikan dalam penelitian ini adalah dakwah politik
Muhammad kepada Raja Heraclius, Kisra Kisra Abrawaiz, Muqouqis, dan Najasyi. Penelitian ini termasuk penelitian kepustakaan (library reseacrh). Metode pengumpulan data dalam penelitian ini adalah dokumentasi.

\section{PEMBAHASAN}

\section{Konsep Dakwah Politik}

Dakwah merupakan segala bentuk aktivitas penyampaian ajaran Islam kepada orang lain dengan berbagai cara yang bijaksana untuk terciptanya individu dan masyarakat yang menghayati dan mengamalkan ajaran Islam dalam semua lapangan kehidupan (Aziz, 2004: 11). Semua bidang kehidupan merupakan sasaran sekaligus medan dakwah. Seluruh kegiatan hidup manusia dapat dijadikan sebagai sarana atau alat dakwah termasuk kegiatan politik (Rais, 1989: 27).Unsurunsur dakwah adalah komponen-komponen yang selalu ada dalam setiap proses dakwah. Ada enam unsur dakwah, yaitu dai(pelaku dakwah), mad'u (mitra dakwah), maddah (materi dakwah), wasilah (media dakwah), thariqah (metode dakwah), dan atsar (efek dakwah)(Aziz, 2004: 75).

Kata "politik" secara etimologis berasal dari bahasa Yunani, politeia, yang berasal dari akar kata polis yang berarti kesatuan masyarakat yang berdiri sendiri atau negara dan kata teia yang berarti urusan. Politik merupakan suatu rangkaian asas, prinsip, keadaan, jalan, cara, dan alat yang digunakan untuk mencapai cita-cita atau tujuan tertentu dalam masyarakat atau negara (Sumarsono, dkk, 2001: 137).

\section{Islamic Communication Journal


Menurut Harold Laswell politik adalah cara untuk membentuk dan membagi kekuasaan (Rasy, 2017: 3). Politik juga didefinisikan sebagai cara dan proses pengelolaan pemerintahan suatu negara. Politik atau siyasah (bahasa Arab) adalah aktivitas atau sikap yang mengatur kehidupan manusia dalam masyarakat. Menurut Ibnu Khaldun (2000, 67) politik adalah sebuah mekanisme yang menjadikan manusia dalam masyarakat berjalan lancar menuju tujuan yang dicitakan bersama.

Unsur-unsur kekuasaan politik sebagai berikut (Zamany, 2015):

1. Negara (state), yaitu suatu organisasi dalam sebuah wilayah yang mempunyai kekuasaan tertinggi yang sah dan ditaati oleh rakyatnya. Unsur-unsur negara meliputi: (a) wilayah, (b) rakyat, (c) pemimpin/pemerintah, pengakuan dari negara lain.

2. Kekuasaan (power), yaitu kemampuan seseorang atau kelompok untuk mempengaruhi tingkah laku orang atau kelompok lain sesuai dengan keinginan para pelaku.

3. Pengambilan keputusan (decision making). Pengambilan keputusan adalah konsep pokok politik tentang keputusan-keputusan yang diambil secara kolektif yang mengikat dan harus ditaati oleh seluruh masyarakat.

4. Kebijakan umum (public policy).

Kegiatan politik suatu negara terbagi atas dua bagian, yaitu politik domestik atau dalam negeri dan politik luar negeri atau hubungan internasional. Politik dalam negeri berhubungan dengan wewenang penguasa untuk mengatur dan memelihara keteraturan dalam negeri. Sedangkan politik luar negeri berhubungan dengan komunikasi dengan negara luar sangat yang ditentukan oleh kekuatan dan kepentingan nasional (Roskin, dkk, 2016: 406).

Menurut Gibson, politik luar negeri adalah rencana komprehensif yang dibuat berdasarkan pada pengetahuan dan pengalaman untuk menjalankan bisnis pemerintahan dengan negara lain. Politik luar negeri suatu negara harus memperhatikan harapan negara lain, entitas internasional, serta standar mapan internasional bagi perilaku nasional sebuah negara. Sumber politik luar negeri suatu bangsa juga harus mempertimbangkan keadaan bangsa, politik domestik, dan kebijakan-kebijakan yang ditetapkan, sebab politik luar negeri merupakan cerminan, perluasan, dan kelanjutan politik domestik (Roskin, dkk, 2016: 134).

Politik luar negeri membutuhkan adanya komunikasi internasional. Komunikasi internasional, menurut Onong Uchjana Effendy, adalah komunikasi yang dilakukan komunikator yang mewakili suatu negara untuk menyampaikan pesanpesan yang berkaitan dengan berbagai kepentingan negaranya kepada komunikan yang mewakili negara lain dengan tujuan memperoleh dukungan, bantuan, dan kerja sama melalui berbagai media komunikasi atau media massa internasional (Shoelhi, 2011: 2-3).

Diplomasi merupakan salah satu bentuk komunikasi internasional yang diperlukan dalam politik luar negeri. Diplomasi adalah kegiatan komunikasi yang dilakukan oleh pemerintahan atau negara dengan pemerintahan atau negara 
lain melalui jalur diplomatik. Jalur diplomatik biasa ditempuh melalui komunikasi interpersonal antar pejabat tinggi negara (Shoelhi, 2011: 6-13). Diplomasi bisa menjadi nilai tawar (state branding) suatu negara. Salah satu media diplomasi adalah surat (Subagyo, 1997: 1$3)$.

Dakwah politik adalah dakwah dengan menggunakan pendekatan struktur politik atau kekuasaan (Fatimah, 2009: 69). Menurut Natsir (1999: 85) dakwah politik adalah dakwah dengan melibatkan aktivitas politik yang bertujuan untuk membela dan menegakkan ajaran Islam yang berasaskan amar ma'ruf nahi munkar. Aktivitas dakwah ini bergerak dan memanfaatkan strukur sosial, politik maupun ekonomi (Sulthon, 2003: xv). Dakwah politik terbagi atas tiga bentuk (Aziz, 2004: 240), yaitu dakwah kepala Negara kepada rakyat, dakwah rakyat kepada kepala negara, dan dakwah kepala negara kepada kepala negara.

Dakwah politik mengintegrasikan dakwah dan politik (Syarif, 2010). Unsurunsur politik dimasukkan dalam aktivitas dakwah. Unsur-unsur politik meliputi negara, kekuasaan, pengambilan kekuasaan, dan kebijakan umum. Unsurunsur dakwah antara lain pelaku dakwah, objek dakwah, pesan dakwah, media dakwah, metode dakwah, dan efek dakwah. Nabi Muhammad telah memberikan contoh proses integrasi politik dalam dakwah Islam yaitu pada periode dakwah di Madinah. Pada periode ini Nabi Muhammad menggabungkan kekuasaannya sebagai pemimpin agama yaitu sebagai rasul Allah dan kekuasaannya sebagai pemimpin politik yaitu sebagai kepala negara untuk menegakkan dakwah Islam.

\section{Surat Nabi Muhammad Kepada Heraklius}

Nabi Muhammad mengutus Dihyah bin Khalifah al-Kalbi, seorang sahabat yang gagah dan cerdas, untuk dikirim kepada Heraklius yang sedang berada di Kota Dimsha, Iliya, Baitul Maqdis Palestina. Dihyah meminta Harits bin Abi Syammar al-Ghassani, wakil raja di Ghassan Irak, untuk membawanya menghadap Heraklius, tetapi Harits tidak dapat memenuhi permintaan itu. Harits mengutus Adi bin Hatim untuk menemani Dihyah menghadap Heraklius.

Sebelum menghadap Herkalius, Dihyah diberitahukan tata karma menghadap raja oleh beberapa pengawal. Saat menghadap Heraklius, Dihyah diharuskan untuk bersujud menundukkan kepala hingga Heraklius mengizinkan untuk mengangkatnya. Dihyah tidak dapat melaksanakan saran dari para pengawal. Dihyah tetap pada pendiriannya bahwa tidak akan bersujud kepada selain Allah (Chalil, 2001: 400).Dihyah menghadap Heraklius yang sedang di dalam ruang sidang yang dihadiri oleh para pembesar Negara dan para pemuka agama Kristen. Dihyah menyerahkan surat Nabi Muhammad yang berbunyi (Bukhari, 1994: 7) sebagai berikut:

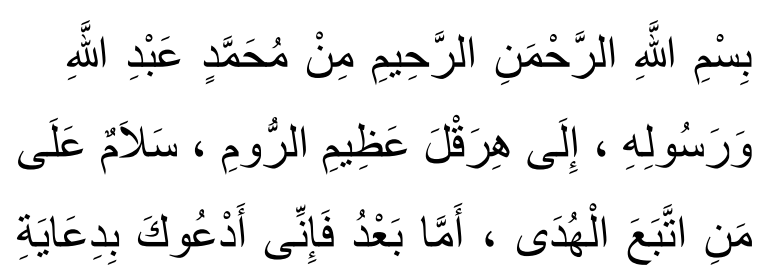

Islamic Communication Journal Volume 4, Nomor 1, Januari-Juni 2019

65 
Agusti Alfi Nurul Insani

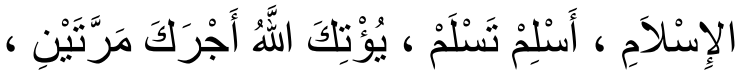

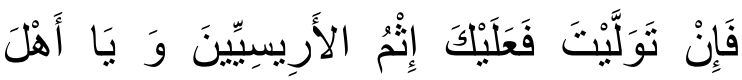

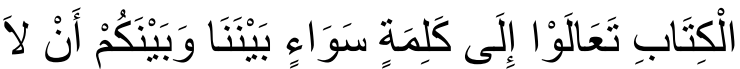

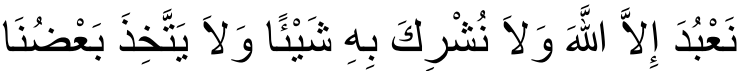

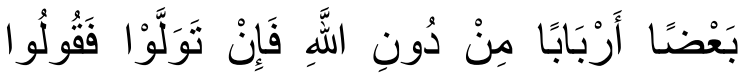

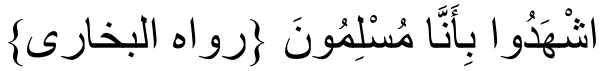

"Bismillahirrahmanirrahiim. Dari Muhammad, hamba Allah dan Rasul-Nya, kepada Heraklius, Kaisar Romawi. Kesejahteraan kiranya untuk orang yang mengikuti petunjuk. Kemudian sesungguhnya saya mengajak anda memenuhi panggilan Islam. Masuklah Islam! Pasti anda selamat, dan Allah akan memberi pahala kepaada anda dua kali lipat. Tetapi jika anda enggan, niscaya anda akan memikul dosa seluruh rakyat. "Wahai Ahli Kitab! Marilah bersatu dalam satu kalimat yang sama antara kami dan engkau semua, yaitu supaya kita tidak beribadah (menyembah) melainkan kepada Allah dan janganlah kita mempersekutukan dia dengan sesuatu. Janganlah sebagian kita menjadikan sebagian yang lain beberapa tuhan yang selain Allah. Jika kamu berpaling, katakanlah oleh kamu (orangorang Islam), 'Saksikanlah olehmu (ahli kitab) bahwa sesungguhnya kami orangorang Islam'. '” (Al-Asqalani, 2010: 57)

\section{Surat Nabi Muhammad kepada Kisra}

Abrawaiz

Surat yang dikirimkan kepada Kisra Abrawaiz disampaikan oleh Abdullah bin Huzafah as-Sahmi (Cholil, 2001: 394). Isi surat (Thabari, 1988: 133) tersebut berbunyi sebagai berikut:

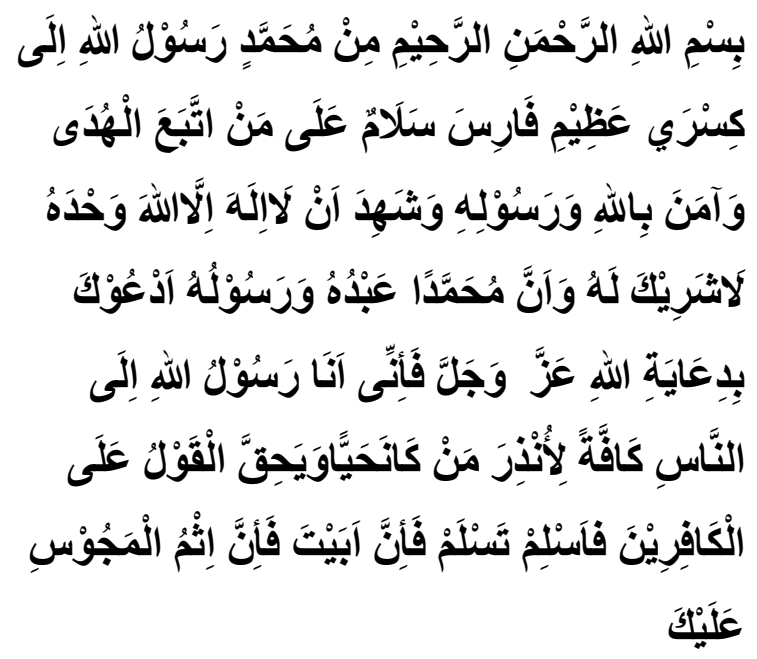

"Dengan menyebut nama Allah Yang Maha Pengasih lagi Maha Penyayang. Dari Muhammad Utusan Allah kepada Kisra Pembesar Persia. Kesejahteraan semoga atas orang yang mengikuti petunjuk (yang benar), yang beriman kepada Allah dan Rasul-Nya, yang telah menyaksikan bahwa tidak ada Tuhan melainkan Allah sendiri- Nya, tidak ada sekutu baginya, dan Muhammad itu hamba dan pesuruh-Nya. Aku berseru kepada engkau dengan seruan Allah Yang Maha Gagah dan Maha Tinggi karen sesungguhnya aku ini utusan Allah kepada umat seluruh manusia, pemberi peringatan kepada orang-orang yang hidup (hatinya) dan supaya pastilah ketetapan (azab) terhadap orang-orang kafir. Islamlah engkau agar engkau selamat. Jika engkau enggan (menolak), sesungguhnya atas engkaulah dosa-dosa orang Majusi." (Cholil, 2001: 395).

\section{Surat Nabi Muhammad kepada Muqauqis}


Surat yang dikirim kepada Muqauqis, Gubernur Mesir, dibawa oleh Hathib bin Abi Balta'ah al-Lakhmi, yang berbunyi sebagai berikut:

بسم الله الرحمن الرحيممِنْ مُحَمّدِ رَسُوْلِ اللهِ

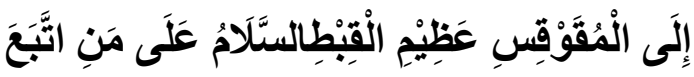

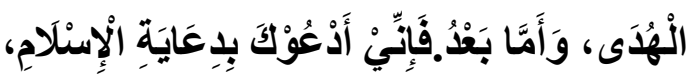

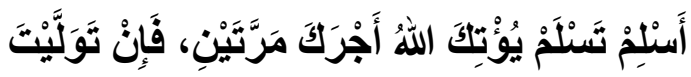

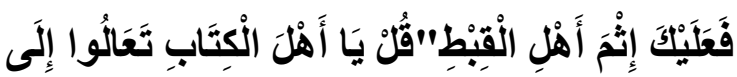

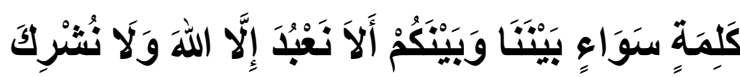

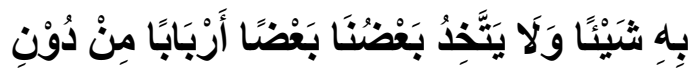

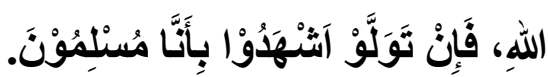

Dengan nama Allah yang Maha Pengasih lagi Maha Penyayang.Dari Muhammad hamba Allah dan utusan-Nya kepada Muqouqis Raja Qibthi. Keselamatan bagi orang yang mengikuti petunjuk. Amma ba'du. Aku mengajakmu dengan ajakan Islam. Masuklah Islam maka engkau akan selamat. Masuklah Islam maka engkau akan diberikan Allah pahala dua kali. Jika kau menolak maka atasmu dosa penduduk Qibthi. Katakanlah: "Hai ahli kitab, marilah (berpegang) kepada suatu kalimat (ketetapan) yang tidak ada perselisihan antara kami dan kamu, bahwa tidak kita sembah kecuali Allah dan tidak kita persekutukan dia dengan sesuatupun dan tidak (pula) sebagian kita menjadikan sebagian yang lain sebagai Tuhan selain Allah". Jika mereka berpaling Maka Katakanlah kepada mereka: "Saksikanlah, bahwa kami adalah orang-orang yang berserah diri (kepada Allah)" (Cholil, 2001: 396).

\section{Surat Nabi Muhammad kepada Najasyi}

Surat yang dikirimkan kepada Najasyi dibawa oleh Amr bin Umayyah adhDhamri (Cholil, 2001: 395), dengan isi surat (Thabari, 1988: 131) yang berbunyi:

بسم الله الرحمن الرحيممِنْ مُحَمّدٍ رَسُوْْلِ اللهِ إلَّى

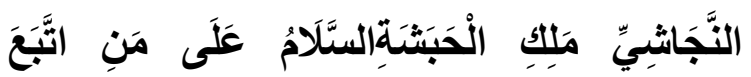

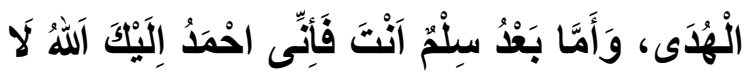

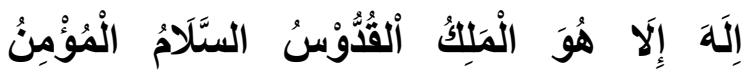

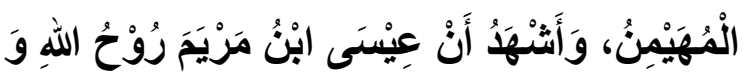

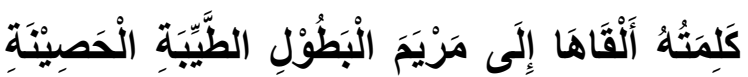

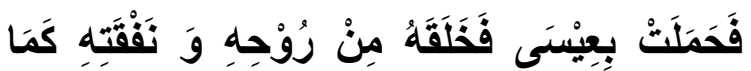

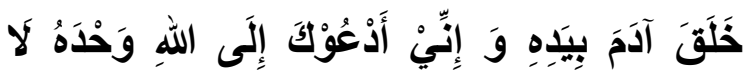

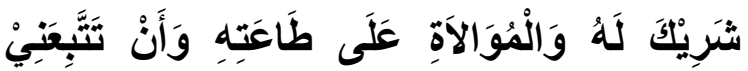

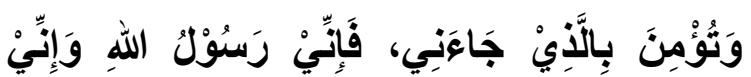

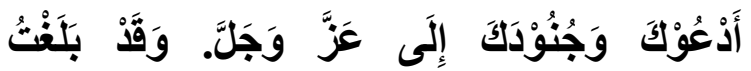

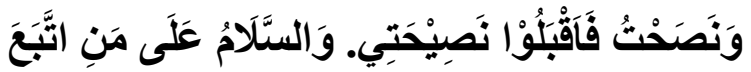
الْهُهُى.

"Dengan nama Allah yang Maha Pemurah lagi Maha Penyayang.Dari Muhammad utusan Allah kepada Najasyi Raja Habasyah, keselamatan bagi yang mengikuti petunjuk.Amma ba'du: aku memuji Allah padamu yang tidak ada Tuhan selain Dia, yang Maha Menguasai, Maha Suci, Maha Penyelamat, Maha Pemberi Aman, dan Maha Pembeda. Aku bersaksi bahawa Isa anak Maryam ruh Allah, dan firman-Nya yang diberikan kepada Maryam yang suci lagi perawan, lalu ia hamil dari ruh dan tiupannya, sebagaiman Ia menciptakan Adam dengan tangan-Nya. Aku mengajakmu kepada Allah yang Esa, yang tidak ada sekutu

Islamic Communication Journal Volume 4, Nomor 1, Januari-Juni 2019 
Agusti Alfi Nurul Insani

bagi-Nya, mematuhi dengan ketaatan kepada-Nya, dan untuk mengikutiku dan mempercayai apa yang aku bawa. Aku Rasulullah, aku mengajakmu dan para pasukanmu kepada Allah yang Maha Perkasa lagi Maha Timggi. Aku telah menyampaikan pesan dan memberi nasihat, maka terimalah nasihatku.keselamatan bagi orang yang mengikuti petunjuk", (Cholil, 2001: 396).

\section{Analisis Isi Surat Nabi Muhammad}

Isi surat Nabi Muhammad kepada para raja secara umum dapat diklasifikasikan menjadi bagian-bagian sebagai berikut:

\section{Permulaan Surat}

Surat Nabi Muhammad kepada Heraklius, Abrawaiz, Muqouqis, dan Najasyi memiliki permulaan surat yang sama, yaitu:

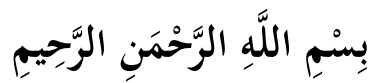

“ Dengan menyebut nama Allah yang

Maha Pengasih lagi Maha Penyayang.,

Penggunaan permulaan surat dengan menyebut nama Tuhan telah menjadi kebiasaan masyarakat Arab sejak beberapa dekade sebelum Muhammad diangkat menjadi rasul. Kebiasaan ini menunjukkan masyarakat Arab yang menjunjung tinggi nilai ketuhanan, terlepas dari kemusyrikan mereka. Sebelum kedatangan Islam, permulaan surat biasanya menggunakan

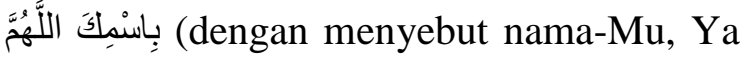
Allah). Masyarakat Arab pra Islam belum mengenal istilah الرَّحْمَن
الرَّحْمَنْن dikenalkan Islam setelah turun QS Al-Isra ayat 110:

$$
\text { قُلِ اذْعُوا اللهَ اَوِ اذْعُوْا الرََّحْمَنِ ... }
$$

"Katakanlah (Muhammad), 'serulah Allah atau serulah ar-Rahman....,"

\section{Kop Surat}

Kop surat Nabi Muhammad berisi nama pengirim surat dan penerima surat. Menurut kebiasaan pada masa itu, orang yang lebih mulia didahulukan dalam penulisan (Cholil, 2004: 404). Berikut penulisan kop surat pada masing-masing surat:

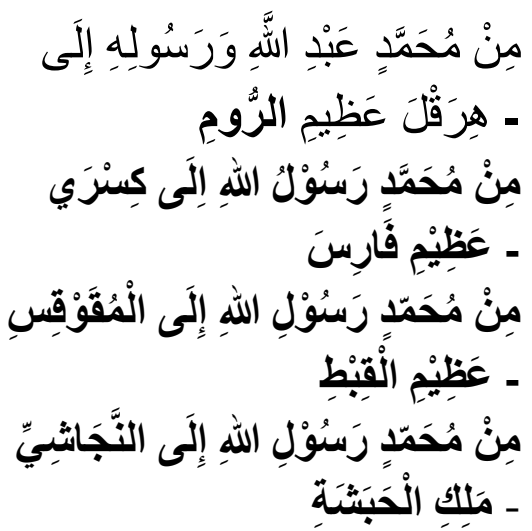

Pada empat kop surat di atas, nama Nabi Muhammad ditulis di awal. Penulisan ini menunjukkan kedudukan Nabi Muhammad lebih mulia dibandingkan para penguasa tersebut. Nabi Muhammad menunjukkan kemuliaannya sebagai utusan Allah untuk mempengaruhi psikologi mad'u sehingga dakwah Islam semakin diperhitungkan oleh mad'u. Meski demikian Nabi Muhammad juga memberikan salam penghormatan yang layak kepada tokoh yang disuratinya. Menurut kebiasaan Arab pada saat itu, sebagai bentuk penghormatan mereka memulai dengan menyebutkan nama orang 
yang lebih mulia baru kemudian gelarnya (Shihab, 2011: 825).

Dua dari empat penguasa yang mengirim surat balasan kepada Nabi Muhammad, yaitu Muqauqis dan Najasyi, menggunakan sistematika kop surat yang sama. Orang yang lebih mulia didahulukan dalam penulisan nama. Muqauqis dan Najasyi mendahulukan nama Nabi Muhammad baru kemudian namanya. Berikut kop surat balasan dari Muqauqis dan Najasyi:

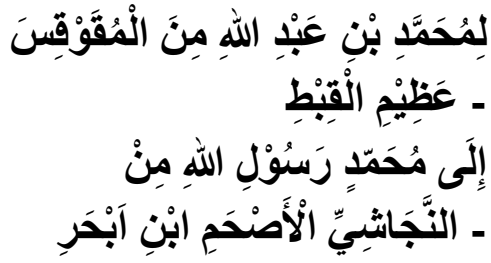

Respon sebaliknya muncul dari Kisra Abrawaiz. Mata Kisra melotot saat sampai pada kalimat, "Dari Muhammad Rasulullah kepada Kisra, Pembesar Negara Persia." Kisra marah karena namanya didahului oleh Muhammad Rasulullah dan berteriakteriak serta merobek-robek surat tersebut walaupun belum membacanya sampai selesai (Cholil, 2001: 405).

\section{Salam}

Kata "salam" berarti keselamatan. Pengucapan salam sudah menjadi kebiasaan seluruh masyarakat pada umunya dan umat Islam pada khususnya. Mengucapkan salam berarti mendoakan keselamatan bagi lawan bicara. Salam yang dituliskan Nabi Muhammad dalam surat yang dikirimkan kepada Heraklius, Kisra Abrawais, Muqauqis, dan Najasyi terbagi menjadi dua bentuk. Pertama, salam yang dituliskan dalam surat kepada Heraklius, Muqauqis, dan Najasyi berbunyi السَََّاُْ عَلَىى
مَنِ انتََّعَ الْهُخَى (keselamatan atas orang yang mengikuti petunjuk). Kedua, salam yang ditulis dalam surat kepada Kisra berbunyi:

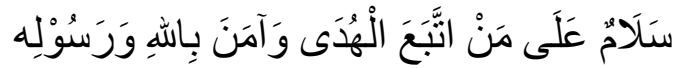

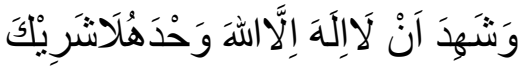

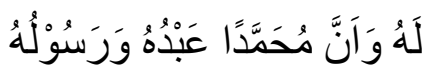

"Keselamatan semoga atas orang yang mengikuti petunjuk (yang benar), yang beriman kepada Allah dan Rasul-Nya, yang telah menyaksikan bahwa tidak ada Tuhan melainkan Allah sendiriNya, tidak ada sekutu baginya, dan Muhammad itu hamba dan pesuruhNya." (Cholil, 2001: 395).

Perbedaan kedua lafal salam tersebut disebabkan oleh latar belakang teologis para penguasa. Heraklius, Muqauqis, dan Najasyi menganut agama samawi, Nasrani, yang sudah mengenal Tuhan Esa dan Nabi Isa sebagai utusan-Nya (An-Nadwi, 2004: 353). Sehingga lafal salam yang ditulis hanya mengandung ajakan untuk mengikuti petunjuk Islam, yaitu pembaharuan keyakinan bahwa Allah adalah Tuhan Yang Esa dan Nabi Muhammad adalah utusan terakhir Allah.

Kisra Abrawaiz adalah penganut Zoroaster, penyembah api (cahaya) sebagai perwujudan Tuhan. Kisra Abrawaiz disebut oleh rakyatnya sebagai raja yang memiliki ketuhanan dalam dirinya, dan dalam ketuhanan ada manusia (Kisra) yang tidak musnah. Kisra memiliki titah tertinggi, kemuliaan agung, dan memiliki cahaya yang menerangi rakyatnya (An-Nadwi, 2004: 355). Oleh karena itu Nabi Muhammad menuliskan salam sebagai penegasan bahwa keselamatan hanya atas

\section{Islamic Communication Journal


Agusti Alfi Nurul Insani

orang yang mengikuti petunjuk Islam, Abrawais, Muqauqis, dan Najasyi, Nabi beriman kepada Allah dan rasul-Nya, serta Muhammad menggunakan lafal 'Amma telah bersaksi bahwa tiada tuhan selain Allah dan Muhammad utusan Allah.

\section{Peralihan Topik}

Al-Bukhari berkata bahwa Ruh bin Abdil Mu'min menceritakan kepada kami, ia berkata, "Abu Usamah menceritakan kepada kami, dari Hisyam bin Urwah, ia berkata, "Aku melihat surat-surat Nabi Muhammad setiap penghabisan satu topik (untuk pindah ke topik lain) beliau bersabda, 'Amma ba'du'." (Azzamy, 2008: 25). Pada surat kepada Heraklius, Kisra $b a$ 'du' pada saat peralihan topik.

\section{Isi Surat}

Secara garis besar, isi surat Nabi Muhammad mengandung tiga bagian, yaitu ajakan masuk Islam, kabar bahagia (tabsyir) berupa pahala apabila menerima dakwah Islam, dan peringatan (tandzir) berupa balasan apabila menolak dakwah Islam. 
Tabel 2. Isi Surat Nabi Muhammad

\begin{tabular}{|c|c|c|c|c|}
\hline $\begin{array}{l}\text { Nama } \\
\text { Mad'u }\end{array}$ & $\begin{array}{c}\text { Ajakan } \\
\text { ber-Islam }\end{array}$ & $\begin{array}{l}\text { Kabar } \\
\text { gembira } \\
\text { (Tabsyir) }\end{array}$ & $\begin{array}{l}\text { Ancaman } \\
\text { (Tandzir) }\end{array}$ & Ayat al-Qur'an \\
\hline Heraklius & أََْْلْم & 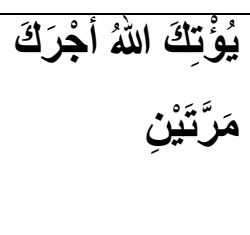 & 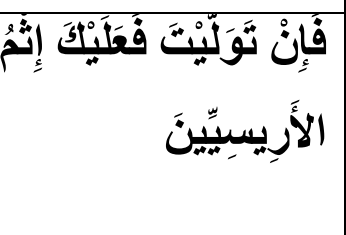 & 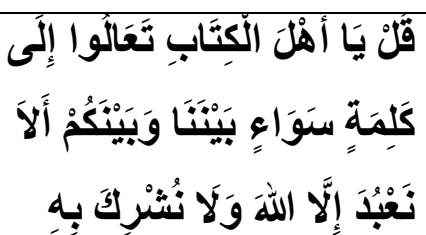 \\
\hline Muqauqis & أَسْْلمْ & 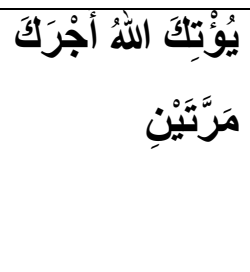 & 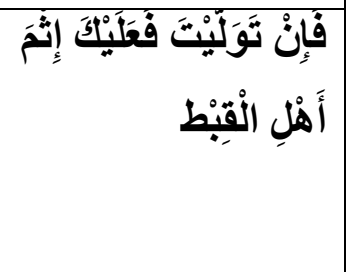 & 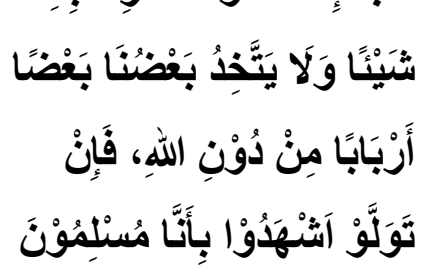 \\
\hline Kisra & أَسَلْمْ & - & 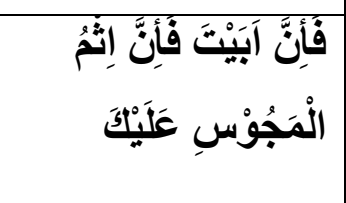 & 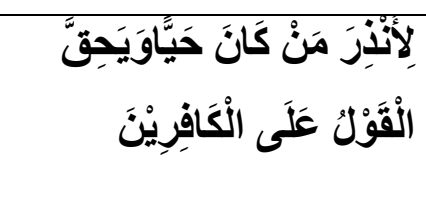 \\
\hline Najasyi & تَأَسْلْمُ & - & - & - \\
\hline
\end{tabular}

a. Ajakan untuk Masuk Islam

Surat-surat Nabi Muhammad memiliki ciri khas, diantaranya adalah isi surat yang singkat dan padat, karena hanya menyampaikan tujuan utama pengiriman tanpa basa-basi (Shihab, 2011: 825). Nabi Muhammad menggunakan redaksi yang tegas dan tanpa basa-basi untuk mengajak para penguasa untuk masuk agama Islam.

Pada masing-masing dari empat surat Nabi Muhammad menggunakan redaksi "أَسْلْمْ تَسْلَمْه" yang artinya ber-islam-lah kamu, maka kamu akan selamat. Menurut kaidah bahasa Arab kata "أَسْْْْْ berbentuk kata perintah (fi'l amr) yang mempunyai akibat (jawab) berupa kata "تَنَلْمَْْ", jadi redaksi tersebut dapat mengandung arti "jika kamu masuk Islam, maka kamu akan selamat. Menurut Ilmi Ushul Fikih, terdapat pembahasan tentang mafhum mukhalafah, yaitu pemahaman yang berbeda (tersirat) dari sebuah teks (Khallaf, 1994: 227). Dengan demikian mafhum mukhalafah dari kata أَسْنْلْ تَسْلَ adalah "jika kamu tidak berislam, maka kamu tidak akan selamat".

Ajakan Nabi Muhammad kepada para penguasa merupakan ajakan yang berani. Nabi Muhammad sebagai kepala negara Islam yang pada saat itu baru berumur enam tahun, berani mengajak para penguasa negara adikuasa untuk masuk Islam dengan konsekuensi apabila para penguasa tidak masuk Islam, maka tidak akan selamat. 


\section{b. Kabar Gembira (Tabsyir)}

Kabar gembira yang disampaikan Nabi Muhammad melalui surat adalah berupa pahala dua kali lipat bagi yang menerima dakwah Islam. Kabar gembira ini tertulis dalam dua dari empat surat, yaitu surat yang dikirim kepada Heraklius dan Muqauqis, dengan redaksi sebagai berikut:

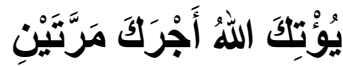

"Allah akan memberikan kepadamu pahala dua kali lipat."

Pahala dua kali lipat adalah balasan dari Allah atas posisi mad'u sebagai penguasa, karena pemimpin diharapkan dapat memberikan pengaruh yang lebih luas terhadap bawahannya (Aziz, 2001: 313). Balasan ini sesuai pula dengan hadits Nabi Muhammad yang berbunyi:

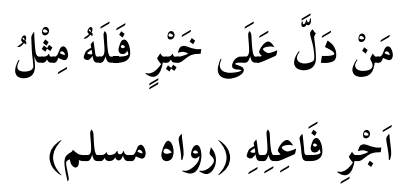

"Barang siapa yang menunjuki kepada kebaikan maka dia akan mendapatkan pahala seperti pahala orang yang mengerjakannya."

\section{c. Peringatan (Tandzir)}

Peringatan yang disampaikan Nabi Muhammad melalui surat adalah berupa dosa seluruh penduduk negeri apabila mad'u menolak ajakan dakwah Nabi Muhammad. Peringatan ini tertulis pada tiga dari empat surat yang dikirimkan oleh Nabi Muhammad, yaitu surat kepada Heraklius, Kisra Abrawaiz, dan Muqauqis.
Peringatan tersebut berbunyi sebagai berikut:

1) Peringatan kepada Heraklius

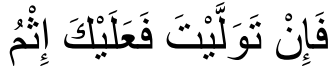

$$
\begin{aligned}
& \text { الأَرِيسبِيِنَ }
\end{aligned}
$$

"Jika engkau berpaling (dari dakwah Islam), maka bagimu dosa bangsa Arizon."

2) Peringatan kepada Kisra Abrawais

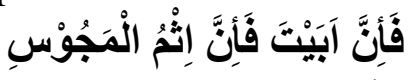

\section{عَلَيْنَ}

"Jika engkau enggan (dari dakwah Islam), maka bagimu dosa bangsa Majusi."

3) Peringatan kepada Muqauqis

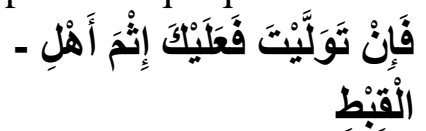

"Jika engkau berpaling (dari dakwah Islam), maka bagimu dosa bangsa Qibthi."

\section{d. Mencantumkan Ayat al-Qur'an}

Surat nabi diawali dengan basmalah dan sering mengutip ayat-ayat alQur'an(Shihab, 2011: 825).Ayat al-Qur'an yang digunakan oleh Nabi Muhammad dalam surat yang dikirim kepada Heraklius dan Muqauqis adalah QS. Ali Imran: 64 yang berbunyi:

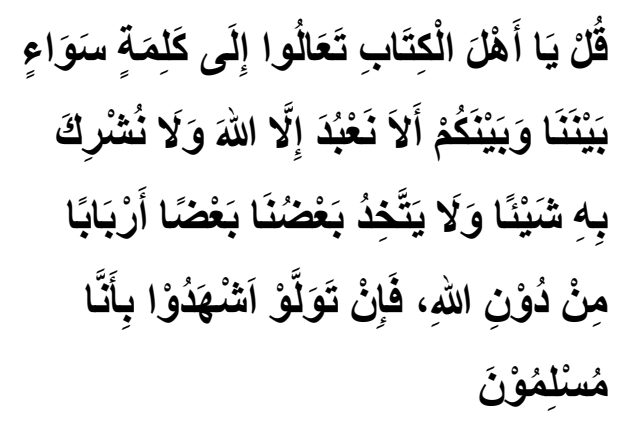

"Hai ahli kitab, marilah (berpegang) kepada suatu kalimat (ketetapan) yang tidak ada perselisihan antara kami dan 
kamu, bahwa tidak kita sembah kecuali Allah dan tidak kita persekutukan dia dengan sesuatupun dan tidak (pula) sebagian kita menjadikan sebagian yang lain sebagai Tuhan selain Allah" (Depag RI, 2005: 58).

Ayat al-Qur'an yang digunakan oleh Nabi Muhammad dalam surat yang dikirim kepada Kisra Abrawaiz adalah QS. Yasin: 7 yang berbunyi:

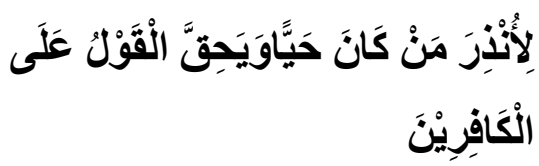

"Untuk memberi peringatan kepada orangorang yang hidup (hatinya) dan supaya pastilah ketetapan (azab) terhadap orangorang kafir” ((Depag RI, 2005: 58).

Nabi Muhammad memilih ayat berdasarkan latar belakang teologis para penguasa. Heraklius, Muqauqis, dan Najasyi merupakan ahli kitab yang sudah mengenal Tuhan Esa dan Nabi Isa sebagai utusan-Nya (An-Nadwi, 2004: 353). Sehingga ayat yang dicantumkan dalam surat adalah QS. Ali Imran: 64. Ayat tersebut mengandung ajakan kepada para ahli kitab untuk berpegang teguh kepada kalimatun sawa (kalimat yang sama antara umat Islam dan ahli kitab), yaitu menyembah Allah dan tidak menyekutukan-Nya dengan suatu pun. Sedangkan Kisra Abrawaiz bukan merupakan ahli kitab. Kisra adalah termasuk orang kafir, sehingga ayat yang dicantumkan adalah QS. Yasin: 7 yang berisi peringatan kepada kepada manusia dan penetapan azab bagi orang-orang kafir.

Berdasarkan hasil analisis isi surat di atas, penulis menyimpulkan bahwa isi surat Nabi Muhammad kepada Heraklius, Kisra
Abrawaiz, Muqauqis, dan Najasyi murni berorientasi kepada dakwah Islam, yaitu mengajak para raja agar memeluk agama Islam. Surat tersebut termasuk surat dinas atau surat resmi, yaitu surat yang dikirim oleh instansi kepada instansi lain atau pribadi dengan menggunakan sistematika tertentu. Surat dinas memiliki sistematika khusus, diantaranya adalah terdapat kop surat dan stempel instansi. (Purwanto, 2006: 178).

\section{Analisis Bentuk Dakwah Politik Nabi Muhammad}

Menurut Moh. Ali Aziz (2004: 240), berdasarkan hubungan $d a ' i$ dan mad'u dakwah politik terbagi atas tiga bentuk, yaitu dakwah kepala negara kepada rakyat, dakwah rakyat kepada kepala negara, dan dakwah kepala negara kepada kepala negara. Dakwah Nabi Muhammad kepada Heraklius, Abrawaiz, Muqouqis, dan Najasyi termasuk ke dalam bentuk yang ketiga, yaitu dakwah kepala negara kepada kepala negara.

$D a$ ' $i$ dalam penelitian ini diperankan oleh Nabi Muhammad. Nabi Muhammad adalah seorang kepala negara. Sasaran dakwah (mad'u) dalam penelitian ini adalah Heraklius, Kisra Abrawaiz, Muqouqis, dan Najasyi. Empat penguasa tersebut merupakan seorang kepala negara. Heraklius adalah kepala negara Romawi. Kisra Abrawaiz adalah kepala negara Persia. Najasyi adalah kepala negara Habasyah. Muqauqis adalah kepala daerah/ gubernur Mesir yang berada di bawah kekuasaan Romawi. Meski bukan seorang kepala negara, tetapi Muqauqis merupakan orang yang berpengaruh, mengingat Mesir pada saat itu adalah wilayah Romawi yang 
Agusti Alfi Nurul Insani

paling kaya dan memberikan banyak suplai kepada negara.

Peran Nabi Muhammad sebagai kepala negara adalah ketika memimpin negara Islam Madinah. Di Madinah Nabi Muhammad menerapkan strategi politik yang berbeda dengan pemimpin politik pada masanya. Madinah dijadikan sebagai negara (state), bukan sebagai kerajaan sebagaimana beberapa kekuasaan di sekitar Jazirah Arab pada saat itu, seperti Kerajaan Romawi dan Persia (Antonio, dkk, 2007: 147).

Negara terdiri atas tiga unsur utama, yaitu warga, wilayah, dan otoritas politik yang mengelola urusan masyarakat (Manan, 2006: 29). Pada periode Madinah, ketiga unsur negara tersebut sudah mampu dipenuhi oleh umat Islam. Madinah adalah wilayah geografisnya. Seluruh penduduk Madinah dan kaum muhajirin adalah penduduknya. Nabi Muhammad adalah kapala negara dan pemegang otoritas pemerintahannya.

Nabi Muhammad memproklamasikan negara Islam pada tanggal 16 Rabiul Awal tahun 1 Hijriyah (20 September $622 \mathrm{M}$ ) dengan ibu kota Madinah. Setelah proklamasi, Nabi Muhammad menyusun pemerintahan dan mengeluarkan Piagam Madinah sebagai manifesto politik yang pertama dalam Islam. Piagam ini mengikat seluruh warga Madinah, yang meliputi kaum muslimin, kaum Yahudi, dan kaum kafir lainnya (Manan, 2006: 37).

Piagam Madinah menetapkan tugas dan kewajiban kaum Yahudi dan kafir Madinah kepada daulah Islamiyah. Dokumen ini juga mengatur dasar-dasar kehidupan sosial, ekonomi, hukum, dan politik segenap penduduk Ma dinah secara adil. Piagam Madinah menetapkan keharusan bergotong-royong untuk mempertahankan kesatuan dan keamanan daulah Islamiyah, termasuk melawan musuh yang datang dari luar. Kaum Yahudi dan kafir Madinah dilarang untuk membantu kaum kafir Makkah, bahkan mereka wajib membantu kaum muslimin untuk belajar berperang.

Setelah Piagam Madinah, langkahlangkah politik strategis terus dilancarkan oleh Nabi Muhammad. Diantaranya adalah Perjanjian Hudaibiyah. Perjanjian ini berlaku pada bulan Zulqaidah tahun $6 \mathrm{H} /$ $628 \mathrm{M}$ dan ditandatangani oleh Nabi Muhammad dan pihak kafir Makkah. Isi perjanjian tersebut, antara lain:

1. Kaum muslimin belum mengunjungi Ka'bah tahun ini, tapi ditangguhkan sampai tahun depan.

2. Kaum muslimin wajib mengembalikan orang-orang Makkah yang melarikan diri ke Madinah. Sedangkan pihak Quraisy tidak harus menolak orangorang dari Madinah yang kembali ke Makkah.

3. Selama 10 tahun tidak diberlakukan genjatan senjata antara masyarakat Madinah dan Makkah.

4. Siapa saja boleh bergabung dengan pihak Muhammad atau Quraisy. Bila ada penyerangan terhadap salah satu pihak atau sekutunya, maka itu melanggar perjanjian.

Perjanjian ini sekilas tampak merugikan kaum muslimin. Isi perjanjian lebih banyak membela kepentingan Quraisy dan merendahkan martabat kaum muslimin. Namun bila dikaji lebih jauh perjanjian ini merupakan pengakuan hormat dan takut 
Quraisy kepada kaum muslimin. Pengakuan ini berdampak positif kepada dakwah nabi. Kondisi ini memberikan kesempatan kepada kaum muslimin untuk menyebarluaskan dakwah Islam dalam situasi yang kondusif, aman, dan tentram.

Salah satu hikmah perjanjian Hudaibiyah adalah semakin luasnya dakwah nabi ke segala penjuru dunia. Kebebasan ini dimanfaatkan Nabi Muhammad untuk mengirim delegasi ke beberapa raja, pemuka agama, dan kepala daerah untuk menyampaikan surat dakwah. Secara struktural para raja merupakan pemegang kekuasaan dan wewenang tertinggi di negerinya. Apabila penguasa dan rajanya sudah masuk Islam, diharapkan rakyat pun mengikuti jejak pemimpin mereka, sehingga Islam akan berkembang lebih luas dan mudah. Demikian pula dengan pemuka agama, mereka adalah pemimpin kultural dalam masyarakat.

\section{Analisis Metode dan Strategi Dakwah Poitik Nabi Muhammad}

Metode dakwah dibagi menjadi tiga, yaitu dakwah lisan (da'wah bi al-lisan), dakwah tulisan (da'wah bi al-qalam), dan dakwah perbuatan (dakwah bi al-hal) (Aziz, 2004: 155). Berdasarkan klasifikasi tersebut, dakwah Nabi Muhammad kepada Heraklius, Abrawaiz, Muqouqis, dan Najasyi termasuk dalam dakwah tulisan (da'wah bi al-qalam). Karya tulis yang digunakan adalah surat.

Tulis-menulis adalah pekerjaan yang sangat diapresiasi oleh Bangsa Arab. Tulismenulis bahkan menjadi salah satu dari tiga syarat utama seseorang yang disebut minal kamilin (diantara orang-orang yang sempurna). Dua syarat lainnya adalah piawai berenang dan pandai memanah. Pada masa jahiliyah, orang yang bisa menulis dan membaca sangat minim. Saat Islam datang, hanya terdapat 17 orang di kalangan kaum Quraisy yang bisa menulis (Azami, 2008: 1-2).

Nabi Muhammad menyadari urgensi tulis-menulis. Setelah negara Islam didirikan di Madinah, Nabi Muhammad sebagai kepala negara mendisiplinkan administrasi negara dan menulis Piagam Madinah. Selain itu surat-menyurat juga merupakan salah satu bentuk kegiatan pemerintahan Islam dalam bidang tulismenulis yang efektif untuk berkomunikasi.

Surat Nabi Muhammad kepada Heraklius, Abrawaiz, Muqouqis, dan Najasyi merupakan salah satu bentuk kegiatan surat-menyurat resmi kenegaraan. Selain dibubuhi stempel, surat Nabi Muhammad yang dikirimkan menggunakan bahasa Arab, bahasa yang berbeda dari bahasa asli empat penguasa tersebut (AnNadwi, 2004: 342). Pemilihan bahasa surat menunjukkan kepercayaan diri Nabi Muhammad mewakili negara Islam yang memiliki basis kekuatan yang mapan. Di sisi lain pemilihan bahasa Arab juga menjadi tantangan bagi utusan yang mengirimkan surat untuk dapat memastikan pesan dakwah tersampaikan kepada para penguasa.

Strategi yang digunakan Nabi Muhammad dalam dakwah politik kepada Heraklius, Abrawaiz, Muqouqis, dan Najasyi adalah diplomasi. Menurut Awaludin Pimay (2005: 50), strategi dakwah adalah proses menentukan cara dan upaya untuk menghadapi mitra dakwah dalam situasi dan kondisi tertentu guna 
mencapai tujuan dakwah secara optimal. Strategi dakwah juga dapat diartikan sebagai siasat, taktik, atau manuver yang ditempuh dalam rangka mencapai tujuan dakwah.

Diplomasimerupakan salah satu bentuk komunikasi internasional yang diperlukan dalam politik luar negeri. Diplomasi adalah kegiatan komunikasi yang dilakukan oleh pemerintahan atau negara dengan pemerintahan atau negara lain melalui jalur diplomatik. Jalur diplomatik biasa ditempuh melalui komunikasi interpersonal antar pejabat tinggi negara(Shoelhi, 2011: 6-13).

Diplomasi bisa menjadi nilai tawar (state branding) suatu negara. Salah satu media diplomasi adalah surat (Subagyo, 1997: 1-3). Demikian pula yang dilakukan oleh Nabi Muhammad dalam dakwah politik kepada Heraklius, Abrawaiz, Muqouqis, dan Najasyi. Selain untuk mengajak para penguasa masuk Islam, Nabi Muhammad ingin menunjukkan branding negara Islam, sehingga peluang dakwah terbuka lebih lebar lagi pada masa yang akan datang.

Hubungan diplomatik memerlukan duta, utusan atau perwakilan (Shoelhi, 2011: 8). Nabi Muhammad sangat memperhatikan pemilihan duta atau utusan untuk menyampaikan surat kepada para penguasa, karena misi dakwah ini memungkinkan akan menghadapi beberapa rintangan. Rintangan-rintangan tersebut antara lain letak geografis yang cukup jauh dari Madinah, perbedaan bahasa, dan kondisi mad'u yang merupakan penguasa dengan pertahanan kuat. Pada akhirnya Nabi Muhammad mengutus Dihyah bin Khalifah al-Kalbi untuk menyampaikan surat kepada Heraklius, Abdullah bin Huzafah as-Sahmi kepada Kisra Abrawaiz, Hathib bin Abi Balta'ah al-Lakhmi, dan Amr bin Umayyah adh-Dhamri kepada Najasyi (Cholil, 2004: 392-396). Utusanutusan tersebut setidaknya memiliki kualifikasi sebagai berikut:

a. Memiliki daya tahan yang kuat

Perjalan dakwah yang dilakukan empat utusan adalah perjalanan yang berat. Para utusan harus melewati bukit dan lembah dengan suhu ekstrim padang pasir seorang diri. oleh karena itu para utusan harus memiliki daya tahan tubuh yang kuat agar misi dakwah dapat berjalan dengan lancar.

b. Memiliki keyakinan mendalam kepada Allah dan pesan dakwah yang akan disampaikan.

Sasaran dakwah pada misi dakwah ini adalah para penguasa yang memiliki keyakinan, kekuasaan dan banyak harta. Para utusan harus memiliki iman yang kuat dan keyakinan mendalam atas pesan dakwah yang disampaikan agar tidak mudah goyah. Salah satu contoh godaan iman dialami oleh Dihyah bin Khalifa alKalbi.

Sebelum menghadap Herkalius, Dihyah diberitahukan oleh beberapa pengawal bahwa saat menghadap Heraklius diharuskan untuk bersujud menundukkan kepala hingga Heraklius mengizinkan untuk mengangkatnya. Dihyah tetap pada pendiriannya bahwa tidak akan bersujud kepada selain Allah (Chalil, 2001: 400).

c. Dapat menjalin komunikasi dengan mitra dakwah 
Kemampuan berkomunikasi yang baik perlu dimiliki oleh para utusan dakwah, karena kemampuan ini menjadi salah satu syarat keberhasilan dakwah. Apabila pesan dakwah berhasil disampaikan dengan baik, maka peluang keberhasilan dakwah akan semakin baik pula. Salah satu kemampuan yang diperlukan dalam dakwah kepada para penguasa adalah kemampuan berbahasa sesuai bahasa mad'u. Ibnu Sa'ad dalam AnNadwi (2004: 342) menyebutkan terdapat yang meriwayatkan bahwa semua orang yang diutus Nabi Muhmmad dapat berbicara dengan bahasa negara tersebut.
d. Memiliki pengetahuan dan wawasan tentang pesan dakwah.

Pesan dakwah mungkin merupakan hal baru yang belum jelas bagi mad'u. Utusan dakwah harus memiliki pengetahuan dan wawasan mendalam tentang pesan dakwah. Apabila sasaran dakwah menanyakan atau bahkan meragukan pesan dakwah, utusan dakwah dapat menanggapinya dengan bijak. Sebagaimana yang dialami oleh Hathib bin Abi Balta'ah al-Lakhmi ketika menghadap Muqauqis (Cholil, 2004: 407).

Muqauqis bertanya, "Bila Muhammad benar-benar Nabi Allah, mengapa musuhmusuhnya dapat mengusirnya dari kampung halamannya dan mengapa ia harus tinggal di Madinah? Mengapa ia tidak mengutuk saja mereka agar dihancurkan Allah?" Muqauqis mengulang pertanyaannya sampai dua kali.

Hathib menjawab, "Bukankah Tuan menyaksikan bahwa Isa bin Maryam itu utusan Allah? Mengapa ia tidak mendoakan kaumnya ketika mereka hendak menangkap dan membunuh dirinya supaya Allah segera menghancurkan mereka, sampai diangkat kepada-Nya?"

Mendengar jawaban Hathib Muqauqis berkata, "Sungguh baik engkau. Rupanya engkau orang yang bijaksana dan datang dari orang yang bijaksana."

Berdasarkan analisis di atas, sistematika dan surat Nabi Muhammad kepada Najasyi memiliki sistematika dan isi yang paling berbeda dibandingkan dengan surat-surat lainnya. Surat kepada Najasyi menggunakan kalimat-kalimat yang menunjukkan kedekatan antara Nabi Muhammad dengan Najasyi daripada penguasa-penguasa lainnya. Surat kepada Najasyi tidak mencantumkan tabsyir dan tandzir sebagaimana pembahasan sebelumnya. Surat kepada Najasyi berisi penegasan keesaan Allah dan nama-nama (asma' al-husna) Allah, pujiian untuk Najasyi, persaksian bahwa Isa adalah salah satu Nabi dan tanda kebesaran Allah (dilahirkan oleh Maryam tanpa ayah).

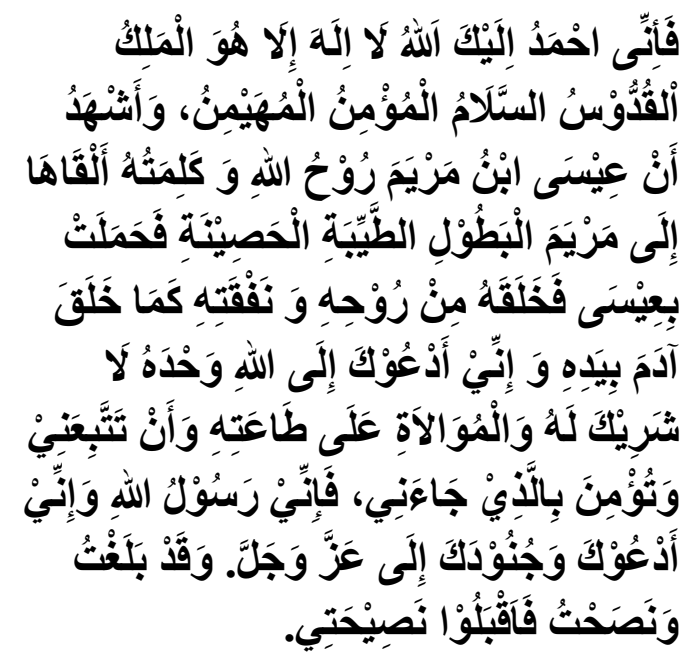

"Aku memuji Allah padamu yang tidak ada Tuhan selain Dia, yang Maha Menguasai, Maha Suci, Maha Penyelamat, Maha Pemberi Aman, dan Maha Pembeda. Aku bersaksi bahawa Isa anak Maryam ruh Allah, dan

Islamic Communication Journal Volume 4, Nomor 1, Januari-Juni 2019 
Agusti Alfi Nurul Insani

firman-Nya yang diberikan kepada Maryam yang suci lagi perawan, lalu ia hamil dari ruh dan tiupannya, sebagaiman Ia menciptakan Adam dengan tangan-Nya. Aku mengajakmu kepada Allah yang Esa, yang tidak ada sekutu bagi-Nya, mematuhi dengan ketaatan kepada-Nya, dan untuk mengikutiku dan mempercayai apa yang aku bawa. Aku Rasulullah, aku mengajakmu dan para pasukanmu kepada Allah yang Maha Perkasa lagi Maha Timggi. Aku telah menyampaikan pesan dan memberi nasihat, maka terimalah nasihatku. Keselamatan bagi orang yang mengikuti petunjuk."

Hubungan umat Islam dengan negara Habasyah dimulai sejak sebelum surat Nabi Muhammad dikirimkan. Ketika periode Makkah dan umat Islam ditindas kaum kafir Makkah, sebagian umat Islam hijrah ke Habasyah dan mendapatkan suaka politik dari Najasyi. Raja Habasyah selalu dijuluki Najasyi, sehingga terjadi kesimpangsiuran tentang apakah Najasyi yang dikirimi surat oleh Nabi Muhammad adalah orang yang sama dengan Najasyi yang memberikan suaka politik umat Islam (An-Nadwi, 2004: 359).

\section{KESIMPULAN}

Setelah melakukan penelitian pada dakwah politik Nabi Muhammad kepada Heraklius, Kisra Abrawaiz, Muqauqis, dan Najasyi, penulis dapat menarik kesimpulan sebagai berikut:

1. Sistematika surat Nabi Muhammad kepada Raja Heraklius, Abrawaiz, Muqouqis, dan Najasyi meliputi permulaan surat, kop surat, peralihan topik, isi surat dan stempel surat. Isi surat Nabi Muhammad meliputi ajakan untuk masuk Islam, kabar gembira (tabsyir), peringatan (tandzir), dan mencantumkan ayat al-Qur'an.

2. Dakwah politik Nabi Muhammad kepada Raja Heraklius, Abrawaiz, Muqouqis, dan Najasyi tergolong dalam bentuk dakwah politik kepala negara kepada kepala negara.

3. Metode dakwah yang digunakan dalam dakwah politik Nabi Muhammad kepada Raja Heraklius, Abrawaiz, Muqouqis, dan Najasyi adalah dakwah tulisan (da'wah bi al-qalam). Strategi yang digunakan Nabi Muhammad adalah diplomasi. Diplomat atau utusan yang ditunjuk Nabi Muhammad memenuhi kriteria-kriteria, yaitu memiliki daya tahan yang kuat, memiliki keyakinan mendalam kepada Allah, menguasai bahasa mad'u, dan memiliki pengetahuan/wawasan tentang pesan dakwah.

\section{DAFTAR PUSTAKA}

Al-Bukhari,Abi Abdullah Muhammad bin Ismail, 1607. Matan Al-Bukhari bi Hasiyah as-Sindi. Beirut: Darul Fikr.

Al-Asqalani, Ibnu Hajar. 2010. Fathul Baari Syarah: Shahih Al-Bukhari. Jakarta: Pustaka Azzam.

An-Nadwi, Abul Hasan Ali Al-Hasani. 2005. Sirah Nabawiyah; Sejarah Lengkap Nabi Muhammad saw, Yogyakarta: Mardhiyah Press.

Antonio dan Muhammad Syafi'I. 2007.

Muhammad Saw: The Super Leader Super Manager. Jakarta: Pro-LM Centre. 
Amin, Samsul Munir. 2014. Sejarah Dakwah. Jakarta:Amzah.

Ath-Thabari, Abi Ja'far Muhammad bin Jarir 1988. Tarikh Ath-Thabari: Tarikh al-Imam wa al-Muluk. Beirut: Darul Kutub al-Ilmiyyah.

Aziz, Moh. Ali. 2004. Ilmu Dakwah. Jakarta: Kencana.

Azzami, Muhammad Mustofa. 2008. 65 Sekretaris Nabi. Jakarta: Gema Insani.

Chalil, Moenawar. 2001. Kelengkapan Tarikh Nabi Muhammad II. Jakarta: Gema Insani.

Departemen Agama RI. 2005. Al-Qur'an dan Terjemahan. Jakarta: PT Syaamil Cipta Media.

Rais, M. Amien. 1989. Cakrawala Islam. Bandung: Mizan.

Shihab, Quraisy. 2011. Membaca Sirah Nabi Muhammad Saw; dalam Sorotan Al-Qur'an dan HaditsHadits Shahih. Jakarta: Lentera Hati.

Shoelhi, Mohammad. 2011. Diplomasi; Praktik Komunikasi Internasional. Bandung: Simbiosa Rekatama.

Syam, Nur. 1991. Metodologi Penelitian Dakwah; Sketsa Pemikiran Pengembangan Ilmu Dakwah. Solo: Ramadhani.

Subagyo, Heni. 1997. Surat-Menyurat Lengkap. Surabaya: Amelia.

Tim penyusun. 1986. Kamus Besar Bahassa Indonesia Cet IX. Jakarta: Balai Pustaka.

Sholikhati, Siti. 2004. Dakwah Islam dalam Kegiatan Politik Pratktis; Antara Tugas Dakwah dan Kepentingan Politik. Jurnal Ilmu Dakwah Vol 24 No. 1.
Sihombing, Buyung Ali. 2004. Menelusuri Dakwah Politik Rasulullah Saw. Jurnal Ilmu Dakwah Vol. 10 Fakultas Dakwah IAIN Sunan Ampel Surabaya.

Zamany, Ahmad Faqih. Disertasi, Dakwah Politik; Telaah Aktivitas Dakwah Anggota DPRD Jawa Timur Periode 2014-2019). digilib uinsby.ac.id. 